\title{
Peacebuilding in Rural Colombia-A Collective Perception of the Integrated Rural Reform (IRR) in the Department of Caquetá (Amazon)
}

\author{
Maximilian Graser ${ }^{1, *}$, Michelle Bonatti ${ }^{1,2}$, Luca Eufemia ${ }^{1} \mathbb{D}$, Héctor Morales ${ }^{1,2}$, \\ Marcos Lana ${ }^{3}(D)$, Katharina Löhr ${ }^{1,4}\left(\mathbb{D}\right.$ and Stefan Sieber ${ }^{1,2}$ \\ 1 Leibniz-Centre for Agricultural Landscape Research (ZALF e.V.), 15374 Müncheberg, Germany; \\ michelle.bonatti@zalf.de (M.B.); luca.eufemia@zalf.de (L.E.); hector.morales@zalf.de (H.M.); \\ katharina.loehr@zalf.de (K.L.); stefan.sieber@zalf.de (S.S.) \\ 2 Department of Agricultural Economics, Humboldt Universität zu Berlin, 10099 Berlin, Germany \\ 3 Crop Production Ecology, Swedish University of Agricultural Sciences (SLU), 75007 Uppsala, Sweden; \\ marcos.lana@slu.se \\ 4 Department of Urban Plant Ecophysiology, Humboldt Universität zu Berlin, 14195 Berlin, Germany \\ * Correspondence: maxgraser@yahoo.de
}

Received: 18 December 2019; Accepted: 22 January 2020; Published: 25 January 2020

\begin{abstract}
The 2016 peace agreement between the Government of Colombia and the FARC-EP created institutional space for an effective implementation of needed rural reforms. However, the change of power structures also contains risks, like the deterioration of natural resources and the strengthening of other armed groups. By addressing collective perceptions regarding the Integrated Rural Reform (IRR), this paper shows the consequences of the peace agreement for the rural population in the department of Caquetá. Additionally, it presents the main challenges for further departmental development. The case study approach uses both semi-structured expert interviews of rural development stakeholders in different sectors based on three sampling strands, as well as participatory observation in the field. The main findings show an increase of general physical security and (economic) interest in the department since the signing of the agreement, while the deforestation rate, homicides, and threats against social-environmental leaders were all highly increased. The study also derives recommendations of departmental actors in rural development for a more effective peace implementation process, like the change from cattle driven to a more conservational economy with agri-silviculture and ecotourism, led by local civil society. To create a stable peace, it is crucial that the current government effectively implements the IRR, while also considering departmental perceptions of sustainable development. If the implementation process and departmental recognition is not enforced sufficiently, then peace might only be possible at the cost of the Amazon and its nature.
\end{abstract}

Keywords: peacebuilding; environmental peacebuilding; Colombia; Caquetá; peace agreement; rural development; natural resource management

\section{Introduction}

After more than half a century of violent conflicts, Colombia commenced an exceptional process toward peace following an agreement between the state and FARC-EP, the leading guerrilla group, that was signed and approved in November 2016. The resulting change in power relations opens new governance spaces for land management in rural areas, which have always been leading cause of disputes in the country [1]. However, as state presence in many conflict regions and sectors is still weak, the development of governmental land use planning also comprises risks for uncontrolled and illicit exploitation of natural resources [2-5]. 
Since the early 1960s, more than seven million people had to flee their homes and between 1985 and 2015, approximately eight million citizens were victimized in Colombia [6,7]. The presence and actions of armed groups caused land abandonment, but also "erosion of civil rule and the almost absolute lack of justice adjudication in the Colombian countryside" for those who stayed [8] (p. 61).

Starting in the 1980s, many peasants had to pay protective duties to occupiers and were forced to produce coca. In the 1990s, small-scale agricultural production increasingly changed to cattle ranching, thus converting former agricultural fields to extensive pastures [8]. Such land use changes, including shifting forestation patterns, like deforestation in former virgin woodlands, are presented as armed conflicts' outcomes [9-11]. However, forest conservation and wildlife protection enforced by the FARC-EP was observed between 2001 and 2010, during the conflict [8,11,12].

The leadership of natural resource governance profoundly impacts peace building and maintenance on national level $[13,14]$. Further, the importance of operative institutions for local development is widely discussed and demonstrated $[15,16]$. However, in Colombia, many studies show that local population needs in rural territories are poorly addressed institutionally $[17,18]$, thereby identifying a general lack of guidelines and weak implementation as well as the application of instruments regarding regional development, land planning, and land use, which threaten national integrity, human livelihoods, and climate change mitigation measures, hence undermining the sustainable development of the country $[2,3,19-21]$.

Studies from the United Nations claim that the cause of the "disruption of state institutions, initiatives, and mechanisms of policy coordination" are violent conflicts [22] (p. 15), whereas other studies see the source of conflict in weak capacities and "institutional failures in dealing with land issues" [23] (p. 99). Hence, weak institutions are a result of armed and violent conflicts but can also be considered as a catalyst for the emergence of armed groups.

Colombia is a centralized state, where policies are developed on a national level, including those operational on the departmental level, even though departments possess a certain degree of autonomy. According to several Colombian scientists, in the post-conflict period, coordination is needed to improve communication within the state across sectors and governance levels, information gaps need to be closed, while national and local institutional capacity must be built. This is considered as crucial not only for stimulating economic growth, but also for protecting ecosystems [2,24]. Strict norms concerning conservation and ecological restoration must be developed to generate control over the most affected and vulnerable regions of the conflict, like the Pacific region, Orinoquía, and the Amazon [25], which involves a challenge to simultaneously integrate local citizens' interests and needs [2,26-28]. In order to create peace and to prevent a relapse into violent disputes, it is equally important that the state considers "the nature as another one of the victims of the 50 years of civil war" [25] (p. 169).

The current peace agreement and peacebuilding efforts are "increasingly compatible with both development and forest conservation" [29] (pp. 2-3). The Integrated Rural Reform (IRR) addresses access and land use, infrastructure and adaption, social development, and encouragement of productivity. It represents the first point of the agreement and was chosen as the unit of analysis (see Table 1). Furthermore, it entails one part of development programs (PDETs) with a territorial focus on particularly conflict-affected rural areas [30]. According to the peace agreement, these programs incorporate municipal as well as departmental authorities for the development of sub-regional planning, as well as proposal development, execution, and monitoring [31]. 
Table 1. Components of the Integrated Rural Reform, part one of the Colombian peace agreement between the government and FARC-EP.

\begin{tabular}{ccccc}
\hline Access and Land Use & $\begin{array}{c}\text { Infrastructure and } \\
\text { Adaptation }\end{array}$ & $\begin{array}{c}\text { Social } \\
\text { Development }\end{array}$ & $\begin{array}{c}\text { Encouragement of } \\
\text { Productivity }\end{array}$ & $\begin{array}{c}\text { PDETs-Programs for } \\
\text { Development with a } \\
\text { Territorial Focus }\end{array}$ \\
\hline $\begin{array}{c}\text { fund for land; integral } \\
\text { access; formalization of } \\
\text { property, restitution of } \\
\text { land, rural land registry, } \\
\text { agricultural jurisdiction, } \\
\text { land suitability, closing of } \\
\text { agricultural frontier and } \\
\text { environmental protection, } \\
\text { peasant reserve zones }\end{array}$ & $\begin{array}{c}\text { country roads, } \\
\text { irrigation districts, } \\
\text { electrification, and } \\
\text { connectivity }\end{array}$ & $\begin{array}{c}\text { health, education, } \\
\text { dwelling water }\end{array}$ & $\begin{array}{c}\text { solidary economy and } \\
\text { cooperative technical } \\
\text { assistance, technology, } \\
\text { research on peasant } \\
\text { economy, financial capital, } \\
\text { social security, food and } \\
\text { nutrition security }\end{array}$ & $\begin{array}{c}\text { poverty, illegal economies, } \\
\text { major institutional debility }\end{array}$ \\
\hline
\end{tabular}

The Colombian constitutional court legally compels the future three national governments to realize and execute the peace agreement [32,33]. The aim throughout this period of the peace process is to design plans on a departmental and local scale, which are developed by three governance authorities on national, regional, and local levels, as well as to implement first measures to develop rural territories in the post-conflict era $[34,35]$.

As a matter of fact, the theory of environmental peacebuilding finds the environment to be a substantial driver of conflicts, but also of conflict resolution and peacebuilding. Environmental peacebuilding is considered a further developed theory out of conventional peacebuilding concepts. Early publications discussing the relationship between the environment and conflicts include GALTUNG [36] and LEDERACH [37]. In the 1987 Brundtland Report, the environment is discussed as a source of conflict. More precisely, environmental related stress is identified as a root of conflict. According to DRESSE et al., natural resources entail diverging interests and values in terms of use, availability, and market value, which makes them a target for politicisation and can lead to disputes and violent conflicts $[22,38,39]$. Apart from having the ability to trigger or contribute to the escalation of a violent conflict, for instance through a settlement strategy for valuable territory and an accompanied coercion for other parts of the population, natural resources and the environment also can become a target (direct or indirect) during violent conflicts. Thus, the environment becomes a weapon, victim, or beneficiary that helps to finance and sustain the conflict [22,38]. Furthermore, conflicts and their outcomes can also beneficially affect the environment. Demilitarized zones, for instance, may facilitate conservation of its biodiversity, creating "ecological heavens" (ibid).

However, studies by Conca and Dabelko [40] or Maas et al. [41] also emphasize features of the environment and natural resources that can help to resolve conflicts and to build sustainable peace. In this sense, the environment possesses a high potential to encourage and enable a dialogue between conflicting parties about shared environmental issues, thus resolving conflict and creating cooperation. Further, environmental cooperation can be the point of origin for the resolution of conflicts as a peacebuilding tool through its official institutionalization. In other words, not only can the environment promote initiatives for improved intergovernmental relations, it can also build societal linkages, as it produces interdependences that can create a regional identity. Here, the environment needs to be governed cooperatively. Only then, if institutions concerning natural resource cooperation are strengthened, can the environment act as a prevention tool against future conflicts $[38,40,41]$.

It is not just Conca and Dabelko who consider the institutionalization of environmental cooperation to be the most important aspect of the concept's success, but also Van Leeuwen and Van Der Haar, who claim that, "In the aftermath of the civil war, many analysts highlight the role of institutions in land disputes" [23] (p. 99). This includes the United Nations, which argues that natural resources can only solidify post-conflict societies and their economy, "if they are managed well" [22] (p. 29). In this sense, environmental cooperation concerning its protection is seen as one pathway toward sustainable peace. 
Studies relating to armed conflict, land-system change, and resource issues are rarely proven empirically, or the topic is insufficiently addressed [23,42,43]. Further, there is a lack of studies in areas where armed conflicts are frequent [42]. While there are investigations into the intensification and recurrence of (armed) resource conflicts, led by circumvention of local institutions [39,44], few address the nexus between natural resources and post-conflict peace in practice as well as its enhancing factors on the interface of local perceptions and institutional governance [45]. Dresse et al. argue that "although recent research strongly suggests that shared natural resources can effectively contribute to building sustainable peace, the question of whether and how this can be effected remains open" [38] (p. 15).

Reinforced through upper research gaps, this research seeks to understand the peacebuilding process and interrelated land-use factors by analyzing the peace agreement implementation process and the concomitant consequences for the rural population of Caquetá. It investigates possible solution paths for sustainable rural development with the environment as a possible peace vector. Therefore, we investigate the perception of the Integrated Rural Reform (IRR), the first point of the agreement among departmental actors in the policy fields of rural development, focusing on the questions:

(1) What effects does the Integrated Rural Reform (IRR) of the Colombian Peace Agreement have on the rural population?

(2) What are resulting key challenges for successfully implementing the IRR?

(3) What are departmental recommendations for rural reform and how do they relate to the IRR?

\section{Materials and Methods}

\subsection{Study Site}

The field research was mainly carried out in Caquetá, as departmental investigation unit. Caquetá was chosen for the following reasons:

(1) It is located in rural Colombia, with a low population and low density [46]. Caquetá covers $88,965 \mathrm{~km}^{2}$ and is the third largest department of Colombia, but only home to half a million inhabitants, representing roughly one percent of Colombia's population. It is located in the occidental part of the Amazon Basin of Colombia, covering roughly one-third of the country's total area. The department's population and infrastructure decline moving eastward, from the Andean piedmont toward the Amazon plains. The highest incomes are generated by the exploitation of land and its natural resources.

Caquetá is Colombia's fifth largest milk producer. The main income sources in the department are generated though large-scale, extensive cattle farming for dairy products, but also meat, where $60 \%$ of the trade is dominated by 250 farmers, causing the most critical conflicts of land use in the Amazon region [47]. Furthermore, agriculture depicts a very important source for income, like the cultivation of African palm, rubber as well as various vegetables and fruits, namely cacao, coffee, rice, beans, corn, watermelon, or yucca. Most products are destined for international exportation [48-50]. Another growing pillar of Caquetá's economic income is extraction of fossil fuels and minerals, such as coal and gold, as well as hydropower plants and catchment lakes [51]. The illegal cultivation of coca (Erythroxylon coca) was a formative phenomenon of the Colombian economy, especially in areas close to the Andean foothills [51,52].

(2) Not only did Caquetá suffer significantly from the civil conflict, it simultaneously lacks national state recognition [53]. Caquetá was marked by forced displacements, expropriation, migration, and victims through the civil conflict (see Figure 1), especially in the 1960s and 1980s. The department was one of the most affected regions during the long-standing armed conflict [54]. Its location between the wetland department Meta in the north, the impenetrable eastern departments of the deeper Amazon, the proximity to the Ecuadorian border vía Putumayo in the south, and the rugged eastern Andean Cordillera in the west, paired with its concurrent provinciality made Caquetá strategically very important for the guerrillas [4]. Accordingly, drug trafficking between the Amazon and the Pacific ports of Tumaco in Nariño or toward Cauca became a main economic activity for the guerrillas. FARC-EP 
were also involved in social, military, and economic control, especially in rural parts, where they even fulfilled judicial responsibilities. Furthermore, they controlled income to rural zones [51].

(3) It includes large and highly important ecological regions. Four national natural parks safeguard approximately $25,000 \mathrm{~km}^{2}$ of the rich biodiversity, including large parts of the Cordillera de los Picachos in the Andes and Serranía de Chiribiquete, which hosts important indigenous petroglyphs and pictographs. However, in 2018, one quarter of Colombia's deforestation, which depicts a loss of 46,765 hectares of rainforest, occurred in Caquetá only [55]. The deforestation is driven by illegal urban settlements and increasing logging activities in the deeper Amazon [50].

(4) There is a lack of scientific knowledge about this region, in both the natural and social sciences, as the research site has been difficult to reach in recent decades.

Therefore, it represents a unique measurable and valuable unit of analysis.

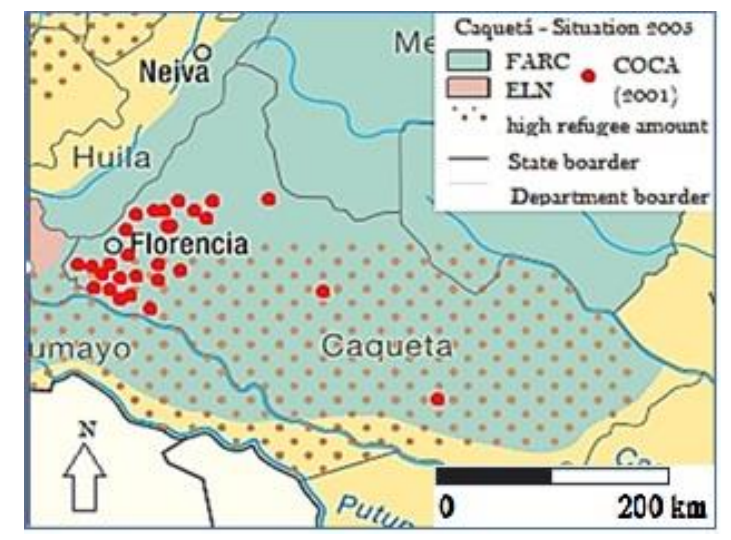

Figure 1. Guerrilla presence and refugee activities (2005) as well as coca production (2001) in Caquetá. Source: reference [33], modified with data from reference [54] (p. 33).

\subsection{Study Design}

In the actualization of the peace agreement implementation process, there is a strong diversity and non-transparency of actors and actions in the field of rural development and its governance, as several new peace agencies have been founded. As a result, a stakeholder and person related approach was chosen to acquire the necessary primary data, framed in a case study design [56,57]. To obtain in-depth understanding of local citizens' interests and needs $[2,27,28]$, the IRR implementation process in Caquetá was analyzed using a qualitative methodological approach, which can be best described as abductive, based on the Grounded Theory developed by Glaser and Strauss [58]. Here, the main objective is not the validation of existing theories, but rather the discovery of innovative theoretical concepts in a processual research approach.

Data collection is based on two qualitative methods: (1) semi-structured interviews and (2) participatory observation. For (1), a total of 17 expert interviews with representatives of major bodies of the public sector (international, national, departmental) and social groups (universities, chamber of commerce, NGOs) in the field of rural development were held. Seven interviews were organized in Bogotá to verify and refine the research question and focus. Subsequently, twelve interviews with in-situ rural development stakeholders in Caquetá were conducted (see Table 2). They were recorded by permission, each taking an average of about $45 \mathrm{~min}$. The questions were formulated openly and were grouped in three categories that align with the main research questions of this paper: (i) effects of the IRR on the rural population; (ii) resulting challenges for its successful implementation; and (iii) recommendations from the departmental level. In accordance with the study design, theoretical sampling was applied to approach persons or groups with diverging positions to the research issue, in order to reach a "theoretical saturation" [59] (p. 164). This open sampling strategy helps to discover relevant aspects of the research field and simultaneously prevents misperceptions of the researcher through ex-ante determinations [60]. In detail, three sampling methods were applied: 
Availability sampling: Here, the most easily accessible interview partners were approached and utilized. Initially, ZALF and further research institutions in the field of land use, rural development, and post-conflict were contacted either by e-mail or via telephone. In this way, primary interviews could be conducted on the national level in Bogotá, mostly entailing universities.

Purposive sampling: In this step, the researchers independently selected relevant interview partners, in this case in Florencia and San Vicente del Caguán with the help of a local "gatekeeper" [59] (p. 164) provided by the International Center for Tropical Agriculture (CIAT).

Sampling using the snowball system: Through this approach, interview partners refer to other important and relevant actors outside of their point of view, which helps with unveiling the non-transparent and rather delicate research field in Caquetá [61].

Table 2. Interviewed actors of rural development and occasions for participatory observation.

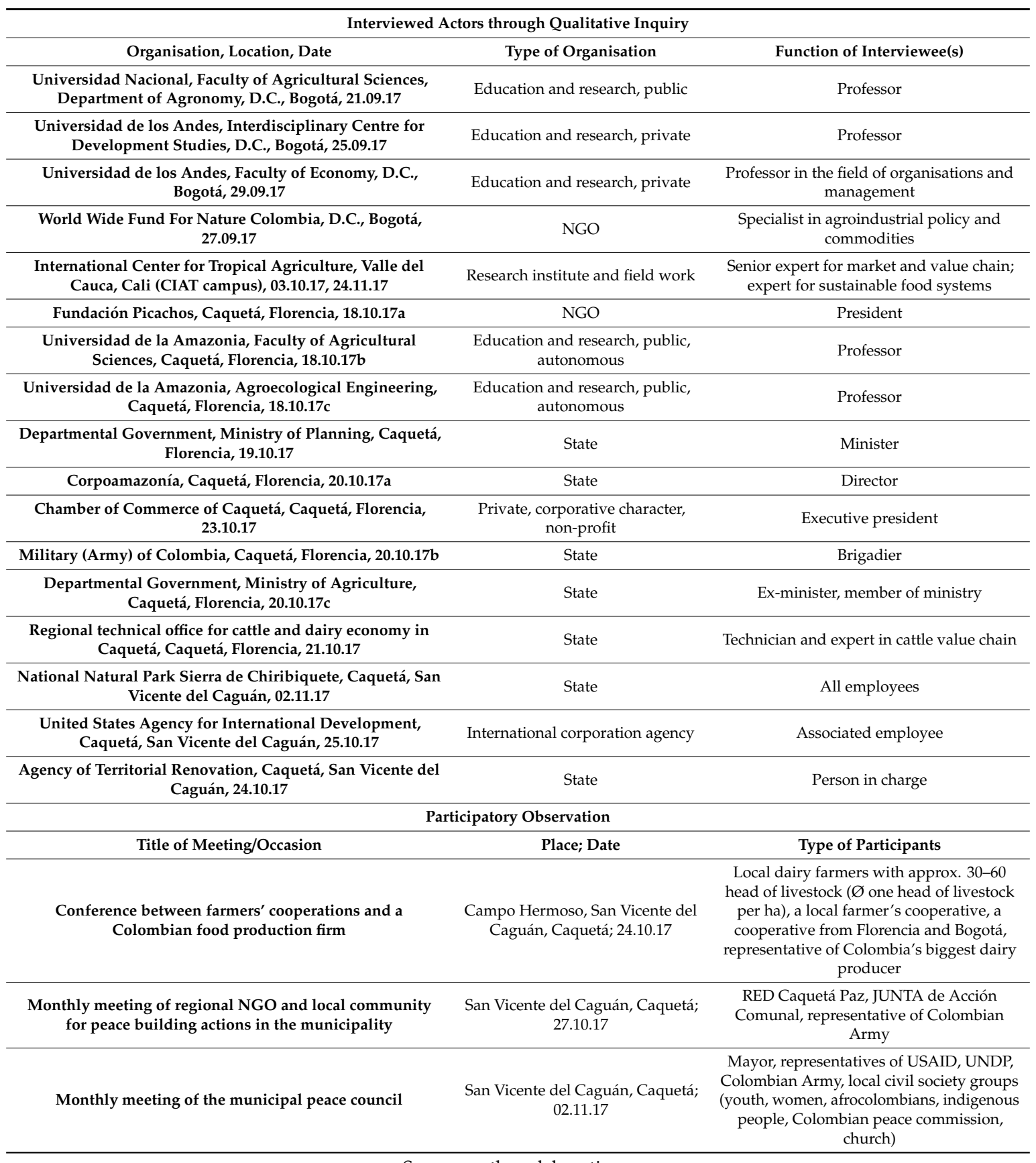


(2) Data collection through participatory observation is especially helpful to understand "processes, organizations, relations, courses of action or patterns of interaction" [62] (p. 855), especially in complex settings, like those in the case of Caquetá. The current situation was observed during three separate research visits to rural Caquetá (see Table 2). As this is an explorative study in a still fragile context, it can be rather difficult to conduct observations at events of rural importance. Nevertheless, this approach aimed to involve one gathering of the most important private sector in Caquetá, one meeting with local civil society representatives, as well as one broader political council addressing the circumstances of peace. This helps to better comprehend the current state of rural development from another, amplified angle.

The analysis of the gathered data follows the approach of Flick [63]: Perceived issues of the implementation process of the peace agreement as well as problem solutions are categorized with umbrella terms which organically evolved through the screening of the transcripts, ranked according to frequency and set into relation with the research objectives. Through this, not just are bottlenecks of prevailing negative issues identified, but also limiting factors and objectives or measures for their resolution are developed [64,65].

\section{Results}

The presentation of the results corresponds to the three leading research questions of the paper. The first and second questions are grouped together, as changes and challenges through the IRR of the peace agreement are closely intertwined. Research question three is presented separately.

\subsection{Effects and Challenges of the Integrated Rural Reform on the Rural Population}

Based on this paper's research, a multitude of positive and negative implications of the peace agreement process are identified, which are summarized in the Table 3.

Table 3. Positive and negative perceptions from the peace implementation process (numbers in brackets show the number of interviewees who mentioned this aspect).

\begin{tabular}{|c|c|c|}
\hline Policy Fields & Positive & Negative \\
\hline Social Changes & $\begin{array}{ll}\text { - } & \text { Physical security }(12 / 12) \\
\text { - } & \text { Higher emotional stability }(4 / 12) \\
\text { - } & \text { Better and more transit }(3 / 12) \\
\text { - } & \text { Better conditions for victims }(2 / 12)\end{array}$ & $\begin{array}{l}\text { - } \quad \text { Little sympathy for the } \\
\text { peace agreement } \\
\text { - } \quad \text { Higher amount of assassinations of } \\
\text { social leaders }(2 / 12) \\
\text { - } \quad \text { Numbness of population }(2 / 12)\end{array}$ \\
\hline Economical Changes & $\begin{array}{l}\text { - Hope for more productive and } \\
\text { prosperous economy }(6 / 12)\end{array}$ & $\begin{array}{l}\text { - } \quad \text { Foreign interest in land } \\
\text { - } \quad \text { Still not many multinationals }\end{array}$ \\
\hline Environmental Changes & & $\begin{array}{l}\text { - } \quad \text { Strong deforestation growth since } \\
\text { peace agreement }(3 / 12)\end{array}$ \\
\hline Political/institu-tional changes & - $\quad$ Space for institutional-building to start & $\begin{array}{l}\text { - Institutional strength is getting worse } \\
(6 / 12) \\
\text { - } \quad \text { Not much advance of peace agreement } \\
\text { implementation yet }(4 / 12) \\
\text { - Other groups have taken space } \\
\text { of FARC-EP }\end{array}$ \\
\hline Other & $\begin{array}{l}\text { - Former great stigmatization of Caquetá } \\
\text { is diminishing/diminished }\end{array}$ & \\
\hline
\end{tabular}

Source: author elaboration.

The most striking finding entails an improved perception of physical security since the peace agreement was signed. All interviewees reported improvements of all-encompassing physical security across Caquetá, especially in rural regions. The violence against civilians and state bodies, prominently 
the military, ceased. The formerly ubiquitous blackmailing similarly stopped. However, despite the improvement of physical security, half of the interviewed stakeholders see a risk for a continuation of violent actions through other autonomous groups, if resocialization and rehabilitation processes of ex-combatants fail. Further, contrary to this positive aspect of social development, two actors clearly spot a much higher quantity of assassinations of social leaders, like those of indigenous origin or of municipal mayors $(20.10 .17 \mathrm{~b}, 18.10 .17 \mathrm{~b})$. The forces behind these attacks were not further elucidated on by the interviewees.

As a result of the renewed stability, mobility patterns also drastically improved. Throughout the conflict, roadblocks and armed assaults on vehicles by guerrillas regularly impeded the free transit of persons and goods, if not making transit outright impossible. Now, even transit in darkness is safely possible. Interviewees report that they are able to reach land that was previously inaccessible or occupied by guerrillas (18.10.17a). Developing Caquetá into a safe and penetrable space also brings foreign transit to the department. Improved accessibility to rural Caquetá raises hope that it will develop a more productive and prosperous economy. Present conditions enable free trade and transport for many products like dairy or fruits, which was not possible during the FARC-EP occupation. The observed activities of Colombia's biggest dairy producer in rural Caquetá are a valid indicator for this development, as well as international corporation's involvement (25.10.17). Beyond that, the economic sector of tourism, which is basically undeveloped in Caquetá, is increasingly important to state actors (20.10.17b). However, an environmental NGO admonishes that, "if the integrated productive development will not work, the absence facilitates the dissidents" (18.10.17a). Four civil society representatives sense a higher emotional stability among the citizens, accompanied by hope in the fulfilment of the IRR.

Despite such positive developments, the confidence, belief, and trust in the government and its plans is still rather low. The transition period between conflict and final peace surprised many people in Caquetá, resulting in a "numbness of the population" (18.10.17b), as a university professor termed it. The population's ongoing doubt is not just directed toward the new living circumstances but also towards the national government and its potential future actions (ibid.).

\subsubsection{Environmental Changes}

All aspects of the environmental changes, mentioned by the interviewees, entail negative environmental development in the post-conflict era, led by strong growth and its resulting "explosion of deforestation" (18.10.17b, 18.10.17c), denounced by professors at the University of the Amazon. Civil society actors recognize an ecological devastation process in Caquetá, which accompanies the rise of deforestation, entailing threats for wildlife, water bodies, and the general biodiversity of the Amazonian rainforest. According to most interviewed stakeholders in rural development in Caquetá, armed groups played an important role in forest area management. In most parts of Caquetá, they controlled the agricultural frontier, hence controlling the size of forest to be used, wildlife protection, and even the management of soil. These elements were determined in local constitutions and monitored at the household level. In addition to conservational control, armed groups were also responsible for the illegal coca production and illegal mining, which led to local exploitation of natural and geological resources with negative impacts on the environment, as pointed out by state actors $(20.10 .17 \mathrm{a}, 20.10 .17 \mathrm{~b})$. In addition, the production of staple foods, like yucca or beans, was under the control of armed groups. With focus on only the armed group's influence on natural resources, it can be noted that all interviewed actors for this topic held that the groups' impact on the environment during the conflict was rather positive because it limited deforestation in the Amazon, which is now intensifying, after the conflict and guerrilla occupation has ceased. One-third of mostly state actors argue that armed groups contributed to the exploitation of the environment in a negative way. Thus, future challenges represent developments in accordance with nature, especially regarding the importance of cattle culture in Caquetá and the growing interest in cattle production and expansion since the 
peace process commenced. The main identified causes here represent extensive cattle ranching and the expansion of road infrastructure. Minor impacts are caused by illegal cultivations and timber cutting.

\subsubsection{Political and Institutional Changes}

Several political and institutional trends can be ascertained, however, most are negative. Half of the interviewees perceive a worsening of institutional structures since 2016. The institutional space that was opened by the withdrawal of armed groups, most importantly FARC-EP, ought to be filled by official public entities; but progress on this point is slow. Hence, state management for many policies is not present, and the operational implementation of the peace agreement stagnates, for instance, for the substitution of coca. There is practical ambiguity between national authorities, with specific competences remaining unclear. This is apparent through agencies that deal with the peace agreement implementation, as well as several development plans, mostly on the national scale, but that overlap in many respects (21.10.17). Additionally, as apparent from observation of the monthly municipal peace council in San Vicente del Caguán, there is inconsistency between local politicians and civil society. The mayor argues that much of the IRR has already been achieved, whereas farmers perceive a lack state support and demand a "peace, that has to be more real."

Furthermore, the national government distrusts municipal development plans, wherefore more time is needed to agree on the peace agreement implementation plans, the PDETs, between national agencies and municipalities (21.10.17). While the process of institutional change is being prolonged, other groups take or have already taken the space of former guerrilla groups $(20.10 .17 a, 20.10 .17$ c, 19.10.17). That is why the challenges for the IRR, according to nine of twelve respondents, represent the improvement of institutional structure settings and political actions. More precisely, better coordination mechanisms and communication, more financial support and non-military state personnel is required. The observation at the monthly meeting of the regional NGO RED Caquetá Paz shows that there are immediate efforts being undertaken by the local rural civil society to support the state in the realization of the IRR by creating a link to the population.

Moreover, the previously poor reputation of the department due to its former violent risks during the intense conflict is now undergoing a substantive change (18.10.17a).

\subsection{Departmental Recommendations for Rural Reforms in the Peace Process}

Three key departmental attempts for more sustainable rural development were ascertained through this study: (a) a change of economic production focus, (b) conservation and economic use of the environment, and (c) civil society empowerment and international support. Two-thirds of the interviewees stress the importance of shifting the economy to focus away from the cattle industry toward alternative forms of production, like silvipastoral systems $(02.11 .17,18.10 .17 \mathrm{c})$, and intensification instead of a further extensivation of cattle production to limit the deforestation impact of ranching activities (19.10.17), or the intensification of marginal sectors to "embrace the possibility of agriculture" (18.10.17b). Consequently, augmented national state long-term financial investment is required in all production sectors, as noted by several interviewees $(20.10 .17 \mathrm{a}, 23.10 .17,18.10 .17 \mathrm{a})$.

Furthermore, five actors consider the environment to be an important asset for future development in Caquetá. Representatives of the National Park Chiribiquete underline the need for the official step to close the deforestation line and to reconvert already deteriorated land in order to achieve the sustainable development of Caquetá's natural resources (02.11.17). Based on a conservational treatment of forest resources, actors emphasize other possibilities of economic exploitation, such as non-timber forest products, payment for forest use, or the possibility of (ecological) tourism to its waters and rainforest (20.10.17a, 19.10.17).

To achieve these goals, the influence of civil society and international corporations is crucial, as the peace agreement does not cover departmental concepts explicitly (23.10.17). Here, actors from civil society, international corporations, and national environmental agencies could depict nodal actors for an integrated institutional management and surveillance of natural resources, including the Amazon. 


\section{Discussion}

Certain issues posed by the interviewees, like specific tools for civil, local, and departmental empowerment, sustainable production pathways, or the issue of corruption are not embodied in the official peace agreement document. Despite increased physical security and transit improvements, considerable threats and violence against social leaders and human rights activists increased concomitantly, as stated by interviewees in Caquetá, but have also been observable at the national Colombian level [2]. In 2017, there were 45\% more murdered activists and ex-FARC-EP members than in $2016[33,66]$.

A study by BORON et al. [67], discussing landscape changes and their effect on rural development in Colombia, recognizes that, within a business as usual scenario, inequality, biodiversity and natural resources as well as food security are negatively affected. Regarding the impacts of the peace agreement and its implementation process in Caquetá, even an intensification of cattle activities, indicated through the interest and presence of the big national dairy product manufacturer Alpina, is perceptible. This differs from interviewee's preferred sustainable production pathways and therefore depicts a symptom of unclear statements in the peace agreement. Additionally, rather weak institutional control capacities in this economic branch might favor further expansion. Moreover, Cheng and Zaum [68] consider economic liberalization during post-conflict transitions to be a supporting instrument for aggravated corruption, which is also a problem mentioned by interviewees (e.g., 18.10.17b).

As concluded by the actors of rural development in Caquetá, the peace process also entails large environmental threats, especially accelerated deforestation and exploitation of the cleared land. Studies and developments show that those perceived effects are real phenomena $[7,55]$. In this regard, environmental protection as one item within the "Access and Land Use" section of the IRR is not ensured.

In 2003, a study by Alvarez [8] mentions the difficulty of forest management in Colombia, as only armed groups form a way of coercive conservation. Further, threats concerning accelerating natural deterioration are identified [4]. Research since signing of the peace agreement finds that since the absence of FARC-EP in rural areas, various legal and illegal industries filled the resulting vacuum, engaging in logging, gold-mining, and increased cattle-grazing [7,33,69], including in Caquetá [70]. The overwhelmingly positive responses of the interviewees regarding the environmental conservation function that FARC-EP provided during their activity can be, consequently, verified through qualitative data.

A lack of formal institutional spaces not only intensifies environmental degradation but also promotes the strengthening of other armed groups, like neo-paramilitaries, ELN or FARC-EP dissidents. This is one effect of insufficient accommodation and reintegration of ex-guerrilla members, who are known to operate in Caquetá [33,71].

Although positive changes are perceptible since the peace agreement was signed, only five percent were implemented within one year [72]. A slow advance of the process was noted by interviewed stakeholders. Further, several investigations show that the institutional positioning of the state is neglected [33,73]. A demonstration by coca farmers in San Vicente del Caguán during the research stay that criticized the weak state enforcement of substitution support, indicates such official non-compliance, including weak social development.

The key challenges for successfully implementing the peace agreement rest upon the government's commitment to effectively implement it. Therefore, the Colombian state must show its presence, reconstructing and reinforcing its governance to overcome its historic institutional fragility $[65,74]$. Equally important is the re-establishment of civilian confidence and trust in official institutions, like the peace agreement. A study by Kurtenbach [75] concludes that Colombian trust in political institutions, like the government, judiciary, and congress, is lower than in their armed forces. Better measurability and visibility of the peace agreement implementation can help to enhance trust, as would focusing on long-term solutions instead of just short-term results [33]. 
Even before the peace agreement was signed, scientists warned against "full-blown, large-scale, unplanned exploitation" [8] (p. 64) on the formerly protected woody areas through guerrillas by the initiated development in the post-conflict situation [11]. As other studies and the results of the present study show, deforestation accelerated enormously, especially in officially protected areas [7].

At the beginning of 2018, President Santos declared the creation of the National Agricultural Frontier (NAF), which involved the opening of 35\% of the national territory for interventions, like agroeconomic, cattle industry, forestry, or fisheries. Currently, 7.6 million ha are cultivated in Colombia, which represent $20 \%$ of the NAF, with $80 \%$ remaining to fill the $35 \%$ of the country's national territory [76]. However, there are no specific regulations in the peace agreement for sustainable land use, like traditional or agroecological farming. This, in turn, facilitates more intensive and competitive forms of land use, further encouraging deforestation, which, paradoxically, should be monitored and restricted through the IRR [30]. These circumstances threaten its successful implementation, not only in Caquetá, but throughout the whole of Colombia.

A study by the United Nations, which derives factors for successful peace construction from lessons of Guatemala, El Salvador, and Rwanda, argues that the stabilization of the agricultural frontier represents an especially important step, as well as the accompanying equal (re)distribution of land $[2,7,11,77]$. In the case of Caquetá, the historical process of land access has its origins in the titling of vacant lots in the forest made by the government throughout the 20th century. The titling process occurred under historical milestones of the armed conflict and led to disputes of land use. Currently, despite the predominance of medium-sized properties in Caquetá, there is still an unequal distribution of land in vacant lots, with large properties representing $1.6 \%$ of the total number of lots awarded and controlling $14.2 \%$ of the total area awarded, while small properties represent $24.7 \%$ and control only $3.1 \%$ of the total area awarded [78]. Thus, the implementation of the IRR is important in order to grant more equal access to land, especially through the enforcement ability by state agencies and their technical capacities to at least secure the NAF $[2,24]$.

In contrast to these rather anxious voices arguing that environmental deterioration consequently threatens successful peace agreement implementation, Alvarez [8] underlines that post-conflict reconstruction "will necessarily involve the country's forest and biodiversity resources" to build peace (p. 65, emphasis in original). This opinion queries the theory of environmental peacebuilding, which sees nature conservation as an instrument to create a common understanding and cooperative usage, thus, in turn, peace. Furthermore, this viewpoint poses another question, regarding accelerated deforestation in the post-conflict of Caquetá: does the environment need to be sacrificed to a certain degree (for instance, within the scope of NAF), so that peace enhancing development steps take place?

According to Reardon [7], conservation objectives must be brought together with addressing the social issues which emerged from the conflict. The challenge, therefore, is to "clarify and secure rights of land tenure and resource access" [77] (p. 63), which is also mentioned by interviewed stakeholders. Namely, landowners, who want to return to their lands, face severe problems because much of their former land was transformed into protected areas. Further challenges for sustainable peace, include delivery of basic services, like energy, health care, and education, as well as equal structural change actions for all inhabitants [11,74]. These points are officially incorporated in the IRR, but are not yet practically enforced, as demonstrations and stakeholder statements illustrate. SCHWARZ and HUCK [33] indicate that a lasting and successful peace depends on the right-wing government of Duque, which agrees with the interviewees' perceptions. Although the Colombian constitutional court legally compelled the government to implement the peace agreement, it can still change items of the document and/or decelerate its process, as the weak promotion of peace talks with other, still existing, guerrilla groups, like ELN, show.

Three action proposals for the improvement of future and current rural development in Caquetá were identified through stakeholder inclusion. Similar to the present research outcomes, other studies on peacebuilding in Uganda and Colombia find that e.g., a change away from cattle ranching as the main source of economic income can generate more jobs in rural areas and, additionally, can consolidate peace 
if the potential of commercial agriculture is taken into account during the process [2,79]. Encouraging the cultivation of global commodities, like coffee, cacao, and tropical fruits can be part of the solution, additionally promoting biodiversity and more forest-friendly land use in rural Colombia [80]. Within Caquetá's development plan from 2016, coffee and cacao were considered as having high potential for the region [81]. Two out of three interviewed stakeholders are open to a change in production, toward the intensification of cattle ranching in order to reduce further expansion, willing to embrace the possibility of agriculture or (agri-) silvicultural systems. BAPTISTE et al. call these rather forest-friendly production methods "the best peacebuilding strategy that Colombia has" [80] (p. 2).

Further, the government of Caquetá recognizes its environmental potential, including its biodiversity of natural landscapes for economic usage, such as ecological tourism [81]. However, the widening of the NAF, weak environmental control mechanisms, as well as interest in cattle industries by large firms indicate a further expansion of cattle ranching. This would mean rather one-dimensional economic growth, which leaves out alternative production and economic conservation possibilities, which are not, or unclearly, formulated in the peace agreement. Such progress can threaten a stable peace and, furthermore, "facilitate the dissidents if the integrated productive development will not work" (18.10.17a).

A 2015 study by the United Nations found that civil society and its organizations, like universities, NGOs, and local communities, are important for determining opportunities for sustainable development by incorporating the natural offer of the locality, hence filling the institutional vacuums left since FARC-EP retrenched [11]. A strengthening of civil society organizations and international corporations is officially anchored in the IRR. As observations in Caquetá show, such development can enhance the empowerment of peasants struggling with insufficient governmental support.

\section{Conclusions}

This paper investigates the effects of the Colombian peace agreement, signed between FARC-EP and the Colombian Government, on the rural population in the department of Caquetá. A number of positive developments occurring since the peace agreement was signed were identified, such as improvements in physical security and prosperous outlooks for economic development in Caquetá. At the same time, shortcomings are also extrapolated by this study: assassination attempts on social leaders increased, deforestation strongly exploded after FARC-EP left, and, in general, the agreement's implementation by the national state lacks sufficient progress. This shows that despite remarkable efforts carried out to create a formal agreement that promotes the nexus between natural resources and peacebuilding, its effective implementation is a complex process that demands augmented inclusion of the interests of local actors.

The resulting challenge is primarily the commitment of the government to effectively implement the agreement. Therefore, simultaneously discovered institutional deficiencies in peace policies need to be tackled on the national level, as weak enforcement exacerbates current problems, especially deforestation. To overcome these shortcomings, this survey extrapolates departmental development paths, entailing alternative small-scale agri-silvicultural production and environmental conservation approaches. To achieve these goals, the influence of civil society and international corporations is crucial, as the peace agreement does not cover departmental concepts explicitly.

Additional case studies addressing the matter of environmental peacebuilding are needed specifically to tackle the question of whether and how shared natural resources can effectively contribute to sustainable peace, as this study shows diverging outcomes to the prevailing view of this theory. It is hoped that the current government will enforce the implementation of the IRR and limit deforestation to prevent peace at the cost of the environment. Further, cooperation among stakeholders is needed in order to achieve widely supported sustainable development in rural Colombia. Otherwise, inadequate land management could create new conflicts. 
Author Contributions: Conceptualization, M.G., M.B., L.E. and S.S.; methodology, M.G., M.B., L.E., H.M., K.L. and M.L.; validation, S.S., H.M. and M.B.; formal analysis, M.G., H.M., K.L. and M.L.; investigation, M.G., L.E.; resources, S.S.; data curation, M.G., M.L. and K.L.; writing—original draft preparation, M.G., M.B.; writing-review and editing, M.G., M.B., H.M., K.L., M.L.; supervision, S.S., M.B., L.E., H.M.; project administration, S.S., M.B.; funding acquisition, S.S., M.G. All authors have read and agree to the published version of the manuscript.

Funding: This research was funded by Stiftung fiat panis and the APC was funded by the Leibniz-Centre for Agricultural Landscape Research (ZALF e.V.).

Acknowledgments: This research is made possible by the Leibniz Centre for Agricultural Landscape Research (ZALF) in Müncheberg, Germany, as part of the ongoing IKI Colombia project; as well as with technical support from the International Centre for Tropical Agriculture (CIAT) in Cali, Colombia.

Conflicts of Interest: The authors declare no conflict of interest. The funders had no role in the design of the study; in the collection, analyses, or interpretation of data; in the writing of the manuscript, or in the decision to publish the results.

\section{References}

1. Fajardo, D.M. Estudio Sobre los Orígenes del Conflicto Social Armado, Razones de su Persistencia y sus Efectos más Profundos en la Sociedad Colombiana; Post-graduate work; Universidad Externado de Colombia: Bogotá, Colombia, 2014.

2. Morales, L. Peace and Environmental Protection in Colombia-Proposals for Sustainable Rural Development; IAD, The Dialogue: Washington, DC, USA, 2017; pp. 1-32.

3. Staub, G.; Hendricks, A.; Navarrete, L.; Thiemann, K.-H. Zum aktuellen Stand der Raumordnung und Landesplanung in Südamerika. Z. Für Geodäsie Geoinf. Und Landmanagement 2016, 4, 252-258.

4. Hoffmann, C. Colombia and the prospect of peace: Is there hope for a slowdown of deforestation in the foothills of the Amazon? An analysis of deforestation patterns and potential preventive measures. Master's Thesis, Humboldt Universität zu Berlin, Berlin, Germany, 2016.

5. Eufemia, L.; Bonatti, M.; Lana, M. Colombia's rural development must honour peace agreement. Nature 2018, 560, 29. [CrossRef]

6. Ibáñez, A.M.; Moya, A.; Arteaga, J. Civil Conflict, Internal Migration, and Monetary Transfers: A Case Study in Colombia; KNOMAD working paper; World Bank: Washington, DC, USA, 2017; pp. 1-44.

7. Reardon, S. Peace is killing Colombia's jungle-and opening it up. Nature 2018, 558, 169-170. [CrossRef]

8. Álvarez, M.D. Forest in the Time of Violence: Conservation Implications of the Colombian War. J. Sustain. For. 2003, 16, 49-70. [CrossRef]

9. Castro-Nuñez, A.; Mertz, O.; Buritica, A.; Sosa, C.C.; Lee, S.T. Land related grievances shape tropical forest-cover in areas affected by armed conflict. Appl. Geogr. 2017, 85, 39-50. [CrossRef]

10. Hurtado, M.; Pereira-Villa, C.; Villa, E. Oil palm development and forced displacement in Colombia: Causal or spurious? Cuad. De Econ. 2017, 36, 441-468. [CrossRef]

11. SINUC - Sistema de las Naciones Unidas Colombia, Consideraciones Ambientales Para la Construcción de una paz Territorial Estable, Duradera Y Sostenible en Colombia: Insumos Para la Discusión. 2015. Available online: http://www.foronacionalambiental.org.co/wp-content/uploads/2015/01/PAZ_AMBIENTE_ COLOMBIA_MADS_NNUU_2014.pdf (accessed on 16 December 2019).

12. Sánchez-Cuervo, A.M.; Mitchell Aide, T. Consequences of the Armed Conflict, Forced Human Displacement, and Land Abandonment on Forest Cover Change in Colombia: A multi-scaled Analysis. Ecosystems 2013, 16, 1052-1070. [CrossRef]

13. Sporsheim Maisto, J. Rethinking Environmental Peacebuilding in the Context of Resource Extraction in Colombia. Master's Thesis, Norweigan University of Life Science, Ås, Norway, 2016.

14. Conca, K.; Wallace, J. Environment and peacebuilding in war-torn societies: Lessons from the UN Environment Program's experience with post-conflict assessment. In Assessing and Restoring Natural Resources in Post-Conflict Peacebuilding; Lonergan, S., Jensen, D., Eds.; Earthscan: New York, NY, USA, 2012.

15. Mikulcak, F.; Haider, J.L.; Abson, D.J.; Newig, J.; Fischer, J. Applying a capitals approach to understand rural development traps: A case study from post-socialist Romania. Land Use Policy 2015, 43, 248-258. [CrossRef]

16. Sangmeister, H. Entwicklung und internationale Zusammenarbeit. Weltwirtschaft Und Int. Zs. 2009, 5, 1-190.

17. Jenss, A. Vertreibung als Strategie: Landkonflikte in Kolumbien. Peripherie 2012, 32, 249-274. [CrossRef] 
18. García, M.; Espinosa, J. El Derecho al Estado. Los efectos legales del apartheid Institucional en Colombia, 1st ed.; Dejusticia: Bogotá, Colombia, 2013; pp. 3-88.

19. Garavito, C.R. ¿Paz territorial sin paz ambiental? El Espectador. 12 February 2015. Available online: http://www.elespectador.com/opinion/paz-territorial-sin-paz-ambiental-columna-543784 (accessed on 29 May 2017).

20. Manetto, F. La propiedad de la tierra, el primer y último eslabón del conflicto armado en Colombia. El País. 27 April 2017. Available online: http://internacional.elpais.com/internacional/2017/04/26/colombia/1493232143_ 781667.html (accessed on 30 September 2017).

21. Suarez, A.; Árias-Arévalo, P.A.; Martínez-Mera, E. Environmental sustainability in post-conflict countries: Insights for rural Colombia. Environ. Dev. Sustain. 2017, 19, 1-19. [CrossRef]

22. UNEP-United Nations Environment Program, From Conflict to Peacebuilding. The role of Natural Resources and the Environment. 2009. Nairobi. Available online: https://postconflict.unep.ch/publications/ pcdmb_policy_01.pdf (accessed on 16 December 2019).

23. Van Leeuwen, M.; Van Der Haar, G. Theorizing the Land-Violent Conflict Nexus. World Dev. 2016, 78, 94-104. [CrossRef]

24. Van Leeuwen, M.; Van Der Haar, G. The Role of Environmental Law in Post-Conflict Peacebuilding. In Governance, Natural Resources, and Post-Conflict Peacebuilding; Bruch, C., et al., Eds.; Earthscan: London, UK, 2016.

25. Aguilar-Garavito, M.; Ramírez, W. La restauración ecológica desde el ordenamiento jurídico colombiano. In Más Allá de la Ecología de la Restauración: Perspectivas Sociales en América Latina y el Caribe; Ceccon, E., Pérez, R., Eds.; Vazquez Mazzini: Buenos Aires, Argentina, 2016; pp. 155-176.

26. Schilling-Vacaflor, A.; Flemmer, R. Rohstoffabbau in Lateinamerika: Fehlende Bürgerbeteiligung schürt Konflikte. GIGA 2015, 5, 1-8.

27. Friedrich-Ebert-Stiftung. Ambiente, Minería y Posconflicto en Colombia: Los Casos del Catatumbo y Sur de Bolívar, 2016, Bogotá. Available online: http://library.fes.de/pdf-files/bueros/kolumbien/12881.pdf (accessed on 16 December 2019).

28. Singelnstein, F. Kontrollierter Landnutzungswandel. Zur Kontrolle von Landnutzungsbedingungen als Mittel der Etablierung territorialer Kontrolle am Beispiel des Oriente Antioqueño, Kolumbien. Berl. Geogr. Blätter 2013, 5, 1-67.

29. Castro-Nuñez, A.; Mertz, O.; Sosa, C.C. Geographic overlaps between priority areas for forest carbonstorage efforts and those for delivering peacebuilding programs: Implications for policy design. Environ. Res. Lett. 2017, 12, 1-11. [CrossRef]

30. Oficina Del Alto Comisionado Para La Paz, El Acuerdo Final de paz. La Oportunidad Para Construir Paz. Gobierno de Colombia. 2016, Bogotá. Available online: http://www.altocomisionadoparalapaz.gov.co/ herramientas/Documents/Nuevo_enterese_version_6_Sep_final_web.pdf (accessed on 11 November 2017).

31. Junguito, R.; Perfetti, J.J.; Delgado, M. Acuerdo de Paz: Reforma Rural, Cultivos Ilícitos, Comunidades y Costo Fiscal. Cuadernos Fedesarrollo 2017, 55, 1-186.

32. Law 02 of 2017 of Colombia. Available online: http://es.presidencia.gov.co/normativa/normativa/ACTO \% 20LEGISLATIVO\%20N\%C2\%B0\%2002\%20DE\%2011\%20DE\%20MAYO\%20DE\%202017.pdf (accessed on 6 August 2018).

33. Schwarz, C.; Huck, A. Kolumbien. Bundeszentrale für politische Bildung. 2018. Available online: http: //www.bpb.de/internationales/weltweit/innerstaatliche-konflikte/54621/kolumbien (accessed on 5 June 2018).

34. Friedrich-Ebert-Stiftung, Guide about the Implementation of the Peace Agreement in Colombia. Research Team of the Caribe Afirmativo Corporation. 2017. Bogotá. Available online: http://library.fes.de/pdf-files/ bueros/kolumbien/13292.pdf (accessed on 16 December 2019).

35. Medina, M.A. Tres agencias para desarrollar el campo en el posconflicto. El Espectador. 7 February 2017. Available online: https://colombia2020.elespectador.com/territorio/tres-agencias-para-desarrollar-el-campoen-el-posconflicto (accessed on 19 October 2017).

36. Galtung, J. Theories of Peace: A Synthetic Approach to Peace Thinking, 1st ed.; International Peace Research Institute: Oslo, Norway, 1967; pp. 1-238.

37. Lederach, J.P. Building Peace: Sustainable Reconciliation in Divided Societies; United States Institute of Peace Press: Washington, DC, USA, 1998; pp. 1-208. 
38. Dresse, A.; Nielsen, J.; Zikos, D. Moving beyond natural resources as a source of conflict: Exploring the human-environment nexus of environmental peacebuilding. Discuss. Pap. 2016, 2, 1-22.

39. Rustad, S.A.; BinningsbØ, H.M. A price worth fighting for? Natural resources and conflict recurrence. J. Peace Res. 2012, 49, 531-546.

40. Conca, K.; Dabelko, G.D. Environmental Peacemaking; Johns Hopkins University Press: Baltimore, MD, USA, 2002; pp. 1-264.

41. Maas, A.; Carius, A.; Wittich, A. From conflict to cooperation: Environmental cooperation as a tool for peace-building. In Environmental Security: Approaches and Issues, 1st ed.; Floyd, R., Matthew, R.A., Eds.; Routledge: Abingdon, UK, 2012; Volume 1, pp. 102-120.

42. Baumann, M.; Kuemmerle, T. The impacts of warfare and armed conflict on land systems. J. Land Use Sci. 2016, 11, 672-688. [CrossRef]

43. Semana, La, A Generar Riqueza Rural. 25 July 2017. Available online: http://www.forossemana.com/evento/ id/22123/a_generar_riqueza_rural (accessed on 21 August 2017).

44. Engels, B.; Chojnacki, S. Landnutzungswandel und Konflikte. Glob. Trends 2013, 1, 307-312.

45. Gierhake, K. Kommunale Anpassung an den Klimawandel-Quito (Ecuador) aus dem Blickwinkel Governmentalität. Zeu Discuss. Pap. 2015, 74, 1-37.

46. Departamento Nacional de Planeación, El Campo Colombiano: Un Camino hacia el Bienestar y la Paz-Misión Para la Transformación del Campo. 2015; Bogotá. Available online: https://colaboracion. dnp.gov.co/CDT/Agriculturapecuarioforestal\%20y\%20pesca/E1\%20CAMPO\%20COLOMBIANO \% 20UN\%20CAMINIO\%20HACIA\%20EL\%20BIENESTAR\%20Y\%20LA\%20PAZ\%20MTC.pdf (accessed on 30 May 2017).

47. Instituto Geográfico Agustín Codazzi (IGAC), Ganadería y Algunos Cultivos se Abren Paso Sobre los Tesoros Ambientales del Caquetá, 2017. Available online: https://www.igac.gov.co/es/noticias/ganaderia-y-algunoscultivos-se-abren-paso-sobre-los-tesoros-ambientales-del-caqueta (accessed on 6 January 2020).

48. Gobernación del Caquetá, Historia del Caquetá. Available online: http://www.caqueta.gov.co/departamento/ historia-del-caqueta (accessed on 30 May 2018).

49. Instituto Amazónico de Investigaciones Científicas. Construyendo Agenda 21 para el Departamento de Caquetá. "Una construcción colectiva para el Desarrollo Sostenible de la Amazonia Colombiana", 1st ed.; Instituto Amazónico de Investigaciones Científicas: Bogotá, Colombia, 2007; Available online: https:/sinchi.org.co/files/publicaciones/ publicaciones/pdf/caqueta.pdf (accessed on 16 December 2019).

50. Fajardo, D. Manejo Integral de Cuencas Hidrográficas a Través del uso de Agroforestería Sustentable en la Amazonia Colombiana, 2012, Corpoamazonia y WWF-Colombia. Cali. Available online: https: //wwf.panda.org/es/?212906/Manejo-integral-de-cuencas- (accessed on 17 December 2019).

51. Meza, C. Recursos y Retos Para el Postconflicto en la Región Huila y Caquetá. Capacidades Locales Para la Paz. Bogotá, Colombia. 2015, pp. 1-31. Available online: http://www.ideaspaz.org/especiales/capacidadeslocales-para-la-paz/descargas/FIP_CartillasRegiones_05HuilaCaqueta.pdf (accessed on 17 December 2019).

52. Oficina de las Naciones Unidas contra la Droga y el Delito de Colombia., Censo de Cultivos de Coca de 2014. No location, Colombia. 2015, pp. 1-152. Available online: https://www.unodc.org/documents/crop-monitoring/Colombia/Colombia_Monitoreo_de_Cultivos_ de_Coca_2014_web.pdf (accessed on 17 December 2019).

53. López, J. Florencia de Caquetá, el hogar de la Manigua. La Tercera. 11 October 2019. Available online: https://www.latercera.com/tendencias/noticia/florencia-de-caqueta/857230/\# (accessed on 23 October 2019).

54. Diaz, A.M.; Sanchez, F. Geografía de los Cultivos Ilícitos y Conflicto Armado en Colombia; Centro de Estudios de Desarrollo Económico Facultad de Economía, Universidad de los Andes: Bogotá, Colombia, 2014.

55. Espectador, El, Caquetá, el departamento con mayor deforestación en 2018. 10 July 2019. Available online: https:/www.elespectador.com/noticias/medio-ambiente/caqueta-el-departamento-conmayor-deforestacion-en-2018-articulo-870343 (accessed on 30 September 2019).

56. Hering, L.; Schmidt, R.J. Einzelfallanalyse. In Handbuch Methoden der Empirischen Sozialforschung; Baur, N., Blasius, J., Eds.; Springer VS: Wiesbaden, Germany, 2014; pp. 529-542. [CrossRef]

57. Meyer, C.; Meier zu Verl, C. Ergebnispräsentation in der qualitativen Forschung. In Handbuch Methoden der empirischen Sozialforschung; Baur, N., Blasius, J., Eds.; Springer VS: Wiesbaden, Germany, 2014; pp. 245-258. [CrossRef] 
58. Glaser, B.G.; Strauss, A.L. The Discovery of Grounded Theory. Strategies for Qualitative Research; Aldine Publishing Company: Chicago, IL, USA, 1967; pp. 1-271.

59. Gebhardt, H.; Glaser, R.; Radtke, U.; Reuber, P. Geographie-Physische Geographie und Humangeographie; Springer VS: Wiesbaden, Germany, 2011; pp. 1-1346.

60. Akremi, L. Stichprobenziehung in der qualitativen Sozialforschung. In Handbuch Methoden der Empirischen Sozialforschung; Baur, N., Blasius, J., Eds.; Springer VS: Wiesbaden, Germany, 2014; pp. 265-282. [CrossRef]

61. Berg, L.B.; Lune, H. Qualitative Research methods for the Social Sciences; Prentice Hall: New Jersey, NJ, USA, 2011; pp. 1-432.

62. Thierbach, C.; Petschick, G. Beobachtung. In Handbuch Methoden der Empirischen Sozialforschung; Baur, N., Blasius, J., Eds.; Springer VS: Wiesbaden, Germany, 2014; pp. 855-866. [CrossRef]

63. Flick, U. Qualitative Forschung: Theorie, Methoden, Anwendung in Psychologie und Sozialwissenschaften; Rowohlt Tb: Hambrg, Germany, 1995; pp. 1-317.

64. Eurropean Commission. Project Cycle Management Guidelines. In Aid Delivery Methods, 1st ed.; European Commission: Brussels, Belgium, 2004; pp. 1-158.

65. Technical Centre for Agricultural and Rural Cooperation. Handbook: Rural Extension, Volume 1-Basic Issues and Concepts; Margraf Publishers: Weikersheim, Germany, 2009; pp. 1-269.

66. Deutsche Welle, Nach Friedensvertrag wieder mehr Gewalt in Kolumbien, 23.11.2017. Available online: https://p.dw.com/p/2o6VU (accessed on 21 January 2018).

67. Boron, V.; Payán, E.; MacMillan, D.; Tzanopoulos, J. Achieving sustainable development in rural areas in Colombia: Future scenarios for biodiversity conservation under land use change. Land Use Policy 2016, 59, 27-37. [CrossRef]

68. Cheng, C.; Zaum, D. Corruption and the Role of Natural Resources in Post-Conflict Transitions. In Governance, Natural Resources, and Post-Conflict Peacebuilding; Bruch, C., Ed.; Earthscan: London, UK, 2016; Volume 1, pp. 461-480.

69. Governor's Climate and Forest Task Force Knowledge Database, Caquetá, Colombia, 2018. Available online: http://www.gcftaskforcedatabase.org/StateOverview/colombia.caqueta (accessed on 15 June 2018).

70. Frankfurter Allgemeine Zeitung. Kolumbien geschaffen: Der wichtigste Ort der Artenvielfalt auf der Welt. 6 July 2018. Available online: http://www.faz.net/aktuell/gesellschaft/tiere/kolumbien-der-groesstetropenwald-nationalpark-der-welt-15672559.html (accessed on 7 July 2018).

71. Ariel-Ávila, A.R. La realidad sobre las disidencias de las Farc. El Espectador. 7 October 2017. Available online: https://www.elespectador.com/colombia2020/pais/la-realidad-sobre-las-disidencias-de-las-farcarticulo-855858 (accessed on 17 December 2019).

72. Observatorio de Seguimiento a la implementación del Acuerdo de Paz. In ¿Es posible una paz estable y duradera sin cumplir el Acuerdo Final? Boletín 004: Bogotá, Colombia, 2017; pp. 1-11. Available online: https://oiapblog.files.wordpress.com/2017/10/informe-4-seracc81-posible-una-paz-establey-duradera-sin-cumplir-el-acuerdo-final.pdf (accessed on 17 December 2019).

73. Keppeler, T. Eine Stadt mit eigenen Gesetzen. Frankfurter Rundschau, 2018; 74 $4^{\text {th }}$ year, No. 47. 15.

74. Unruh, J.; Williams, R.C. Land: A foundation for peacebuilding. In Land and Post-Conflict Peacebuilding, 1st ed.; Unruh, J., Williams, R.C., Eds.; Routledge: London, UK, 2013; pp. 1-20.

75. Kurtenbach, S. The challenges of institutional reforms in the midst of war. Lessons from Colombia. In Institutional Reforms and Peacebuilding; Studies in Conflict, Development and Peacebuilding; Ansorg, N., Kurtenbach, Eds.; Routledge: London, UK, 2017; pp. 93-113.

76. Gobierno de Colombia, Gobierno definió Frontera Agrícola Nacional para avanzar hacia el desarrollo rural sostenible y proteger la biodiversidad, Bogotá, Colombia, 2018. Available online: http://es.presidencia.gov.co/noticia/180621-Gobierno-definio-Frontera-Agricola-Nacional-paraavanzar-hacia-el-desarrollo-rural-sostenible-y-proteger-la-biodiversidad (accessed on 30 June 2018).

77. Webersik, C.; Levy, M. Reducing the Risk of Conflict Recurrence: The Relevance of Natural Resource Management. In Governance, Natural Resources, and Post-Conflict Peacebuilding; Bruch, C., et al., Eds.; Earthscan: London, UK, 2016.

78. Centro Nacional de Memoria Histórica (CNMH), La Tierra No Basta. Colonización, baldíos, conflicto y organizaciones sociales en el Caquetá, 2017. Available online: http://babel.banrepcultural.org/cdm/ref/ collection/p17054coll2/id/97 (accessed on 6 January 2020). 
79. Klein, D.; Joras, U. Natural Resources and Peacebuilding. In Governance, Natural Resources, and Post-Conflict Peacebuilding; Bruch, C., et al., Eds.; Earthscan: London, UK, 2016; Volume 1, pp. 931-949.

80. Baptiste, B.; Pinedo-Vasquez, M.; Gutierrez-Velez, V.; Andrade, G.I.; Vieira, P.; Estupinán-Suárez, L.M.; Londono, M.C.; Laurance, W.; Lee, T.M. Greening peace in Colombia. Nat. Ecol. Evolut. 2017, 1, 1-3. [CrossRef] [PubMed]

81. Gobierno del Caquetá, Plan Departamental del Desarrollo-“Con Ustedes Hacemos más por el Caquetá 2016-2019". Florencia, Colombia. 2016. Available online: https://es.slideshare.net/YOLANDASILVA11/plande-desarrollo-con-usted-hacemos-mas-por-el-caquet-20162019 (accessed on 17 December 2019).

(C) 2020 by the authors. Licensee MDPI, Basel, Switzerland. This article is an open access article distributed under the terms and conditions of the Creative Commons Attribution (CC BY) license (http://creativecommons.org/licenses/by/4.0/). 